\title{
Competence in Bacillus subtilis Transformation System
}

\author{
By S. HORVÁTH \\ Institute of Genetics of the Hungarian Academy of Sciences, Budapest
}

(Accepted for publication I2 September 1967)

\section{SUMMARY}

Changes in competence of Bacillus subtilis 168 try $^{-}$in relation to generation time and under other conditions were examined. When the generation time increased or decreased from that associated with maximum competence, competence decreased. In a culture in balanced growth, competence remained at the same level for long periods. In supplemented medium, more bacteria became competent than in minimal medium.

Aeration stimulated the development of competence which reached a higher peak than in an unaerated culture. When the medium was inoculated with spores, competence also developed. The smaller the inoculum of spores, the later the appearance of competence.

Waves of competence were often seen along the main curve of competence, and were influenced by the compositions of the media and by the inoculum size.

During the growth cycle in a closed culture the bacterial cells became competent and then lost this property. Competence was thus a transient state.

The optical density of the bacterial suspension was a good guide to the development of competence, but varied with the strains used and with the cultural conditions.

\section{INTRODUCTION}

Many bacterial species are able to take up deoxyribonucleic acid (DNA) when in a state of 'competence' and can then be transformed (Alexander \& Redman, 1953; Klein \& Klein, 1953; Balassa, I954; Bracco, Krauss, Roe \& MacLeod, I957; Corey \& Starr, I957; Hotchkiss, 1957; Spizizen, I958; Goodgal \& Herriott, 196I ; Catlin \& Cunningham, 1964). The DNA derived from bacteriophage (Romig, I962; Green, I964; Okubo, Strauss \& Stodolsky, 1964; Reilly \& Spizizen, I965) or virus (Abel \& Trautner, 1964; Bayreuther \& Romig, 1964) can similarly be incorporated in competent bacteria where it can replicate.

Competence is often short-lived and occurs only under special growth conditions. Many factors influence its appearance and therefore its nature has not yet been well defined. One of the important factors is the generation time and experiments have been carried out to investigate in detail changes of competence in relation to generation time. The connexion between competence and synchrony of cell division was also investigated.

\section{METHODS}

Bacterial strains. In the transformation experiments the recipient strain was Bacillus subtilis 168 try ${ }^{-}$, and the donor strain B. subtilis MARBURG. Both were kindly provided by Dr B. S. Strauss.

Media. Bacterial strains were maintained on potato agar (Spizizen, I958; Nester, 
1964). Bacillus subtilis I68 try- was precultivated on minimal glucose yeast agar slope (MGY agar). The development of competence was investigated in MGY liquid medium. T-medium was used for transformation, and MG-agar for the selection of transformants: both media are described by Horváth (1967).

Transforming DNA of Bacillus subtilis MARBURG was prepared by the phenol extraction method of Saito \& Miura (1963; Horváth, 1967).

Determination of competence and the transformation procedure were previously described in detail (Horváth, 1967).

Cultivation of the bacterial suspensions were carried out in a water bath at $37^{\circ}$ on a reciprocal shaker at $100 \mathrm{rev} . / \mathrm{min}$. During growth, samples were taken and assayed for the number of competent bacteria by transformation to prototrophy under standard conditions. The number of transformants was calculated from two replicate measurements.

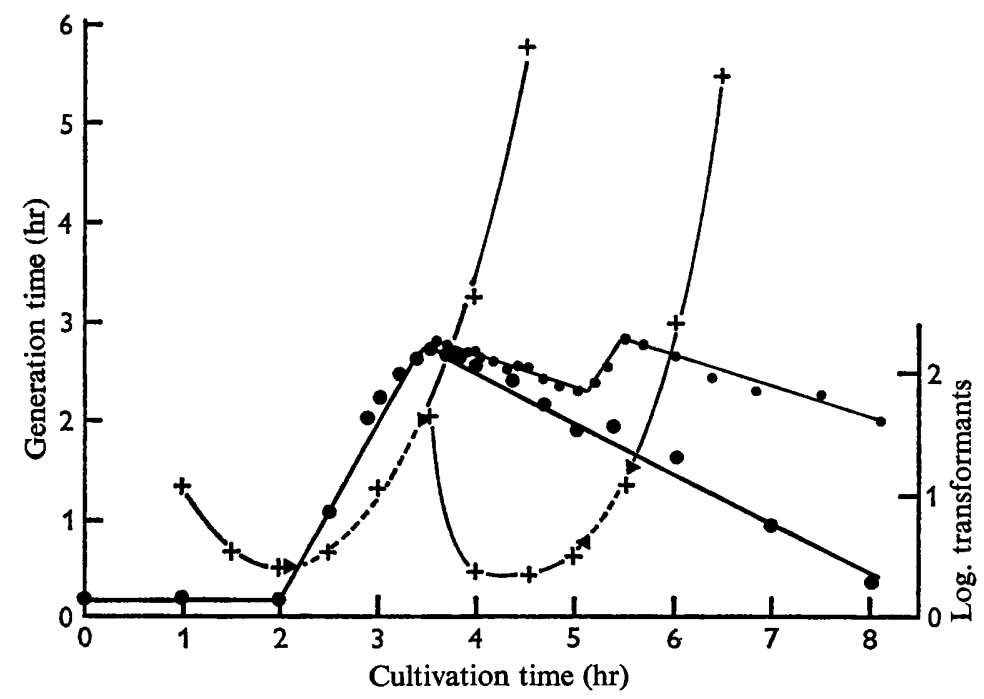

Fig. I. Correlation between generation time and competence during the cultivation in two flasks. The thin lines represent the values in the second flask. The dotted lines along the curves of the generation time represent the rise phase of competence. $+\longrightarrow+$ generation time.

Balanced growth was obtained by diluting the bacterial suspension with MGY liquid medium every Io min. The optical density (OD) then remained 'almost constant' for long periods during cultivation. After diluting the bacterial suspension sufficient culture was discarded to maintain the original volume of the culture.

Chain formation was determined by microscopy and counts analysed statistically by expressing the number of bacteria per chain in $\log _{2}$. The number of bacterial chains was expressed in per cent (Horváth, 1967).

\section{RESULTS}

\section{Correlation between generation time and competence}

The preceding paper (Horváth, 1967) showed that the generation time played an important role in the development of competence. In the following experiment Bacillus subtilis 168 try- was cultivated and the generation time of the bacterial suspension 
changed from time to time during incubation. $5.9 \times 10^{7}$ cells $/ \mathrm{ml}$. of OD about $0^{\circ} \mathrm{I}$ were inoculated into Io $\mathrm{ml}$. MGY liquid medium in a $100 \mathrm{ml}$. Erlenmeyer flask fitted with side arm for OD measurements. During subsequent incubation and growth, samples were assayed for the number of competent bacteria by measuring the efficiency of transformation to prototrophy under standard conditions. The optimal competence was determined according to OD value. When the bacterial suspension showed optimal competence a small portion was put into a second Erlenmeyer flask and diluted with MGY liguid medium to 0.I OD value. In the first flask the generation time increased, in the second it decreased during cultivation.
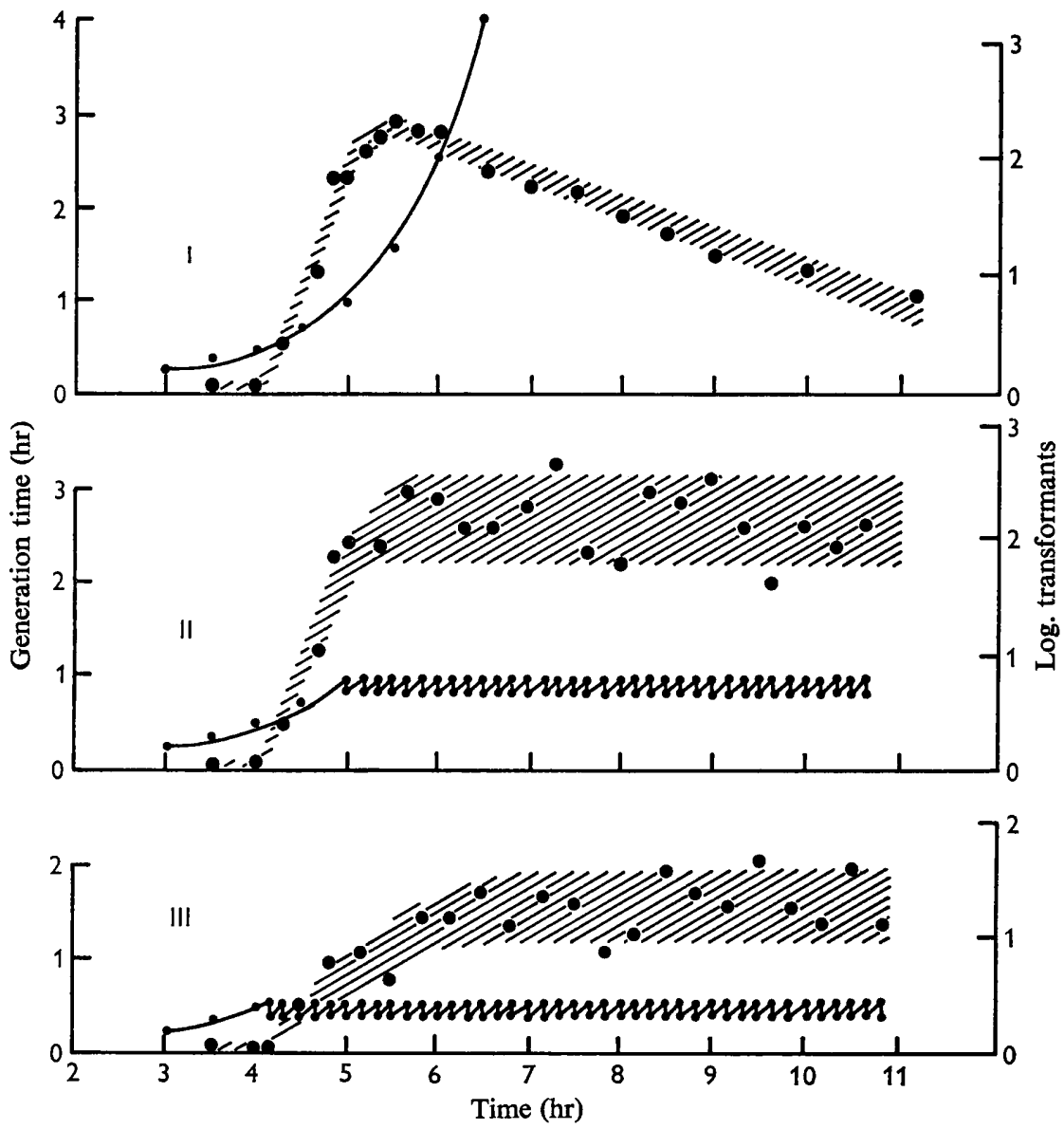

Fig. 2. Changes of competence in the balanced growth cultures. time. Shadowed area represents the competence.

Changes in competence in relation to the generation time are shown in Fig. I.

In the first flask, competence followed the same course as in previous experiments (Horváth, 1967). In the second flask the curve of competence had a different shape because competence decreased for $\mathrm{I} \cdot 5 \mathrm{hr}$, then increased for a short time, and finally decreased. It was easy to fix the peak of competence in the second flask by controlling the OD value of the bacterial suspension. At this time a small portion of the cell 
suspension from the second flask was diluted with MGY medium to an OD of $0 \cdot 1$, and incubation continued. Competence was determined as before. The result was exactly the same as in the second flask.

These curves showed that competence depended on change in generation time. When the generation time increased or decreased from the optimal value, in both cases the competence decreased.

\section{Changes of competence during balanced growth}

Three bacterial suspensions were incubated in MGY liquid medium. In the first flask, the organisms multiplied in a closed culture. In the second flask balanced growth was maintained at a generation time of 50-55 min., and in the third the generation time was 25-30 min. During growth small portions of the cultures were taken and then

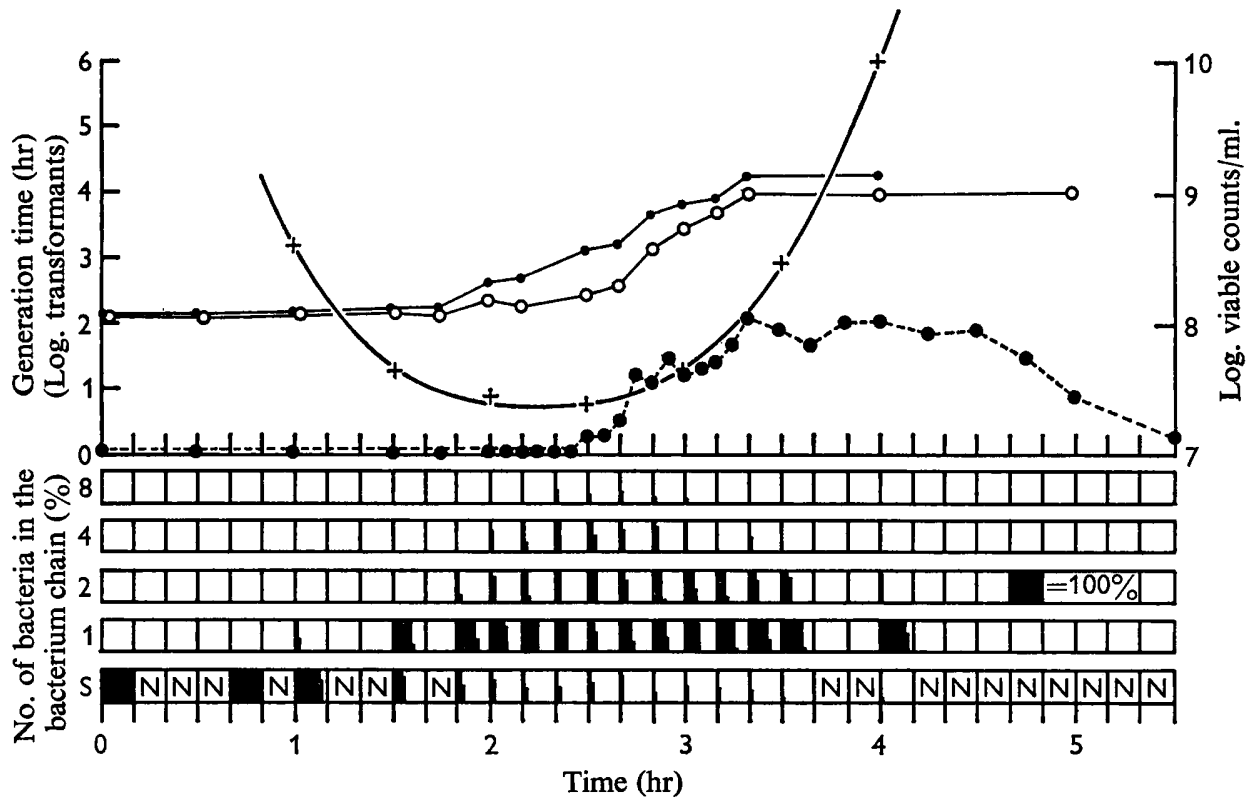

Fig. 3. Development of competence in MGY medium inoculated with spore suspension. Chain formation expressed in per cent. - - - - , Number of transformants; +- + generation time; $\mathrm{O}-\mathrm{O}$, uncorrected viable counts; $\longrightarrow$, corrected viable counts. $\mathbf{S}=$ spores. $\mathbf{N}=$ not tested.

competence assayed. Figure 2 shows that competence increased or decreased as a function of the generation time. In balanced growth, competence remained at the same level during cultivation.

Relation between competence and cell division. It is an open question how the celldivision rate influences competence. To investigate this problem it is best to synchronize the culture from the time when competence appears (when the shortest generation time begins to increase). This is not easy to do and therefore a spore suspensions of Bacillus subtilis I68 try- was inoculated into MGY medium and incubated as usual. During growth, the competence, viable count, generation time and chain formation were determined (Fig. 3). 
Figure 3 shows that competence developed when the generation time began to increase (after $2.5 \mathrm{hr}$ ), and its peak appeared after $3 \mathrm{hr} 20 \mathrm{~min}$.

Spores took a long time to germinate and so a synchronized culture could not be obtained. During growth the bacteria remained attached to each other after division and formed chains. After $2 \mathrm{hr} 20 \mathrm{~min}$., $5 \%$ of the cells divided at least 3 times. During this period no competent bacilli were seen, but the generation time was then at a minimum. After $2.5 \mathrm{hr}$ incubation cell division was asynchronous and we could not demonstrate a step like growth curve.

Viable counts were made on MGY agar. According to the uncorrected values, the bacteria began to multiply after $2.5 \mathrm{hr}$. When correction was made for chain formation, the corrected curve was obtained. According to this, the bacteria began to divide after I hr 45 min. incubation.

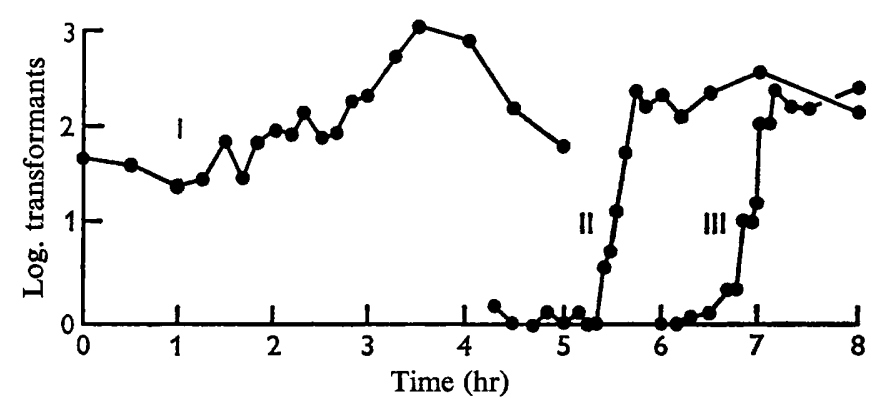

Fig. 4. Waves of competence in MGY media inoculated with different numbers of $B$. subtilis $168 \mathrm{try}^{-}$. The inoculum size: I, $2.95 \times 10^{8} / \mathrm{ml}$; II, I $\cdot 18 \times 10^{5} / \mathrm{ml}$; III, $7.45 \times 10^{3} / \mathrm{ml}$.

Waves often appeared in the main curve of competence. In the following experiment three competence curves were determined at different occasions. MGY media were inoculated with different numbers of organisms and the number of transformants was determined from 5 replicate measurements (Fig. 4).

Figure 4 shows that the bigger the inoculum of bacteria, the bigger the waves of competence. When a small number of organisms was inoculated into the medium very small waves were seen. Three waves could be distinguished in curve I. The differences between the highest and lowest values of the waves were significant $(P<0.02)$.

The waves were bigger when the MGY media contained less yeast extract or when minimal media were used.

An extremely marked wave of competence was demonstrated in the following experiment: $3.6 \times 10^{6}$ bacilli $/ \mathrm{ml}$. were inoculated into MGY medium and grown only to $0.33 \mathrm{OD}$ in order to keep the generation time short $\left(\mathrm{I} \cdot 9 \times 10^{8}\right.$ bacteria $/ \mathrm{ml}$.). After centrifugation at $1600 \mathrm{~g}$ for $5 \mathrm{~min}$., the packed organisms were resuspended in $5 \mathrm{ml}$. supernatant at $\mathrm{I} \cdot 95 \mathrm{OD}$, and incubation continued until the OD rose to 2.4 . During growth samples were taken for transformation to prototrophy and chain disruption was controlled (Fig. 5). During growth the bacteria divided very slowly. The short chains split up to give individual bacteria.

When a large number of organisms is inoculated into the medium cell division is nearly synchronous thereafter, it may be supposed that the waves were caused by the last cell division, before the development of sporulation. 
Development and changes in competence under different conditions

The effect of differing amounts of yeast extract in MGY liquid media was tested. An overnight culture was used as an inoculum to give at the beginning of the experiment an OD value of 0.1 . The numbers of transformants at the peaks of competence are shown in Fig. 6.

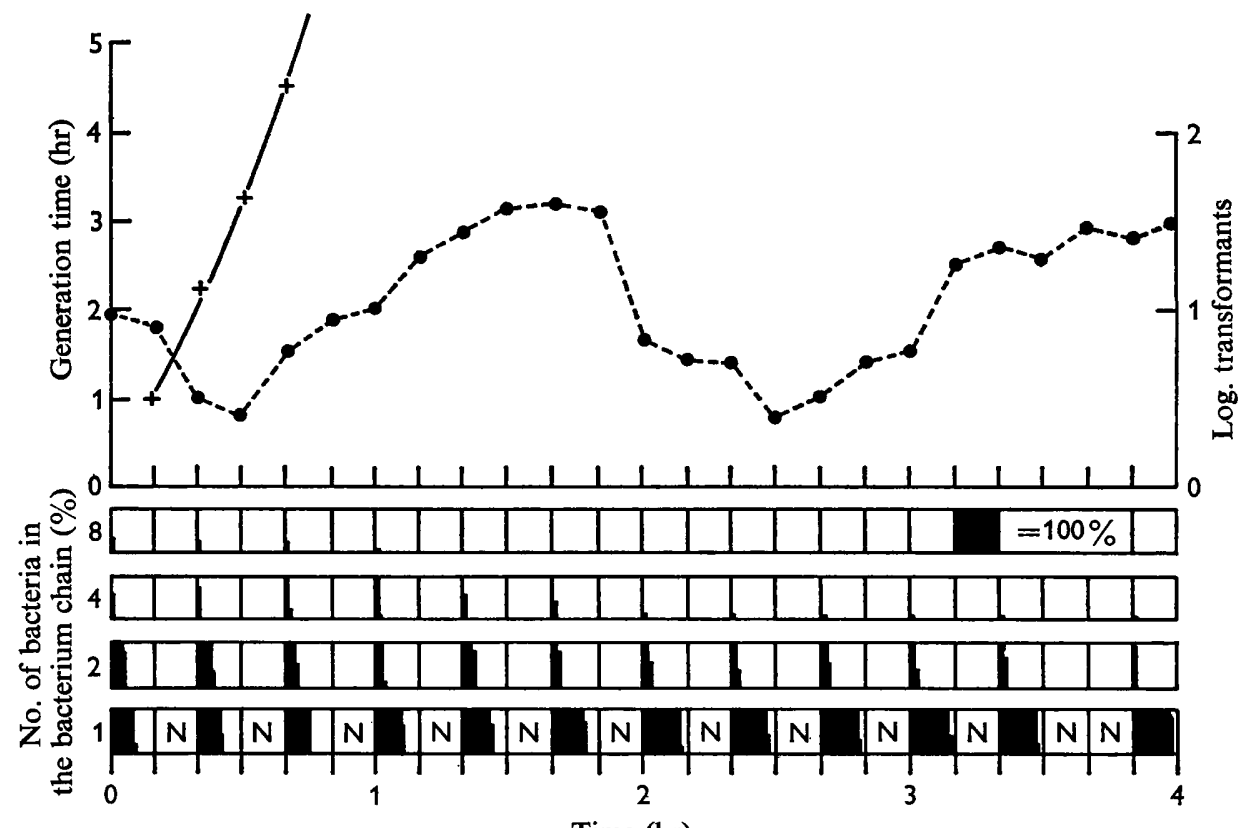

Time (hr)

Fig. 5. Waves of competence in MGY medium inoculated with $1 \cdot 15 \times 10^{\circ}$ organisms $/ \mathrm{ml}$. of a well-grown B. subtilus $\mathrm{I} 68 \mathrm{try}^{-}$suspension. - - +-+ , generation time. $\mathrm{N}=$ not tested.

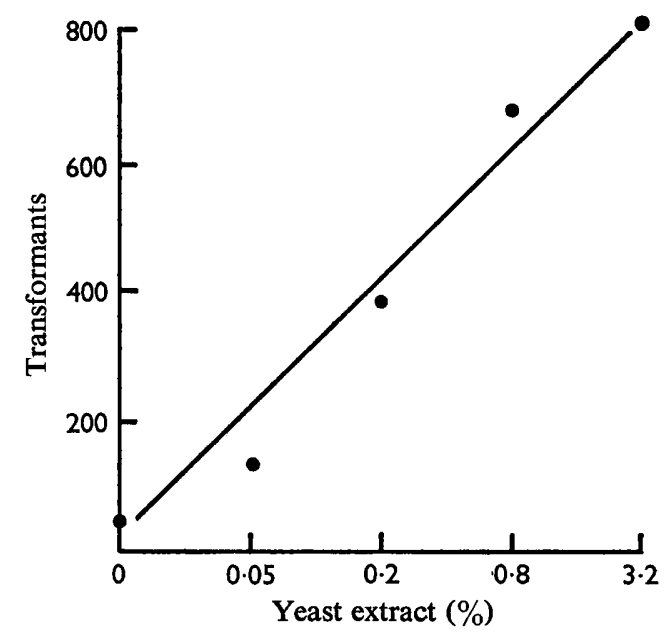

Fig. 6. Peaks of competence in MGY media containing different amounts of yeast extract. 
Earlier the peak of competence was obtained with the smaller quantity of yeast extract. In Fig. 6 it is clearly seen that the peaks of competence are higher when larger amounts of yeast extract are used.

Bacillus subtilis 168 try $^{-}$was inoculated into three flasks of MGY medium. The first was shaken during incubation, the second one shaken only for $3 \mathrm{hr}$, and the third one incubated without shaking. The results are shown in Fig. 7.

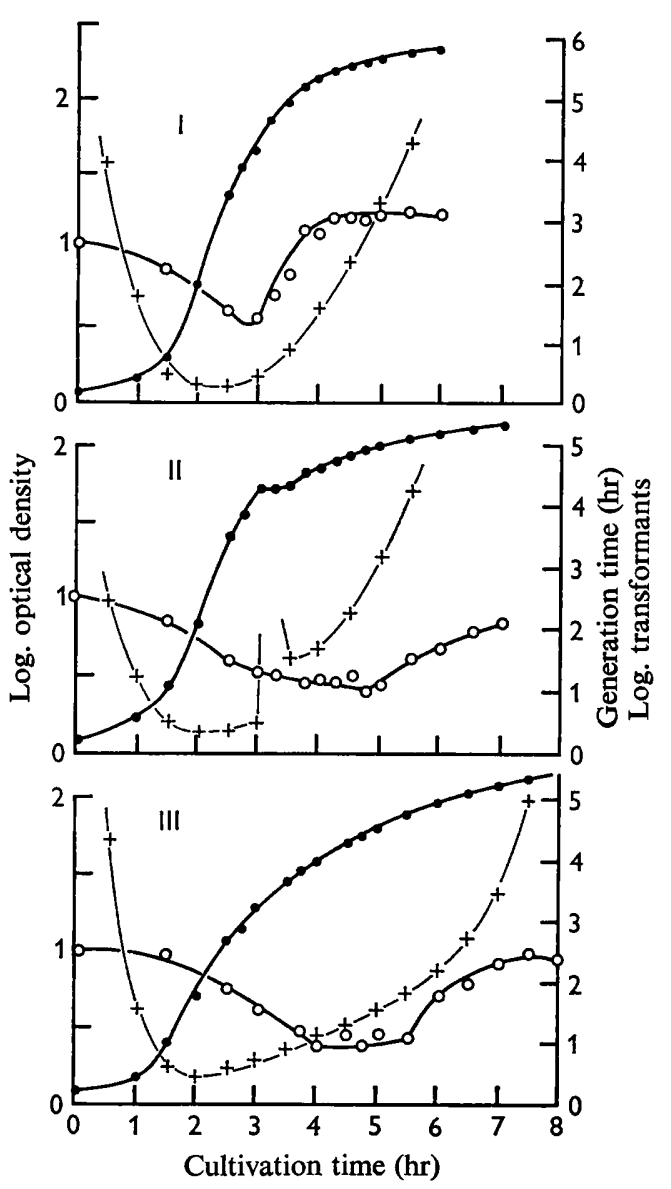

Fig. 7
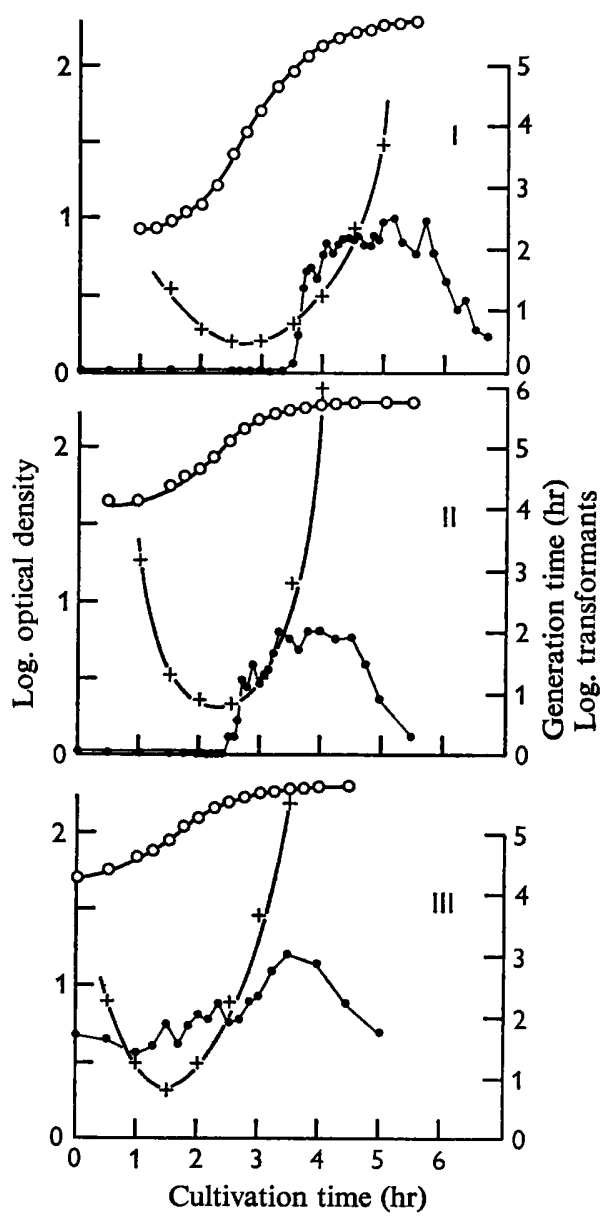

Fig. 8

Fig. 7. Development of competence in MGY medium in different amounts of oxygen. $\mathrm{O} \mathrm{O}$, competence; $\longrightarrow$, optical density; +-+ , generation time.

Fig. 8. Development of competence in MGY medium inoculated with spore suspension and precultivated organisms. $\mathrm{O}-\mathrm{O}$, optical density; $-\longrightarrow$, competence; +-+ , generation time.

In Fig. 7, I. Competence developed when the bacterial cells were shaken. During incubation competence decreased and after $3 \mathrm{hr}$ increased quickly again up to a high degree.

In Fig. 7, II, shaking was stopped after $3 \mathrm{hr}$. For this reason competence could not develop as in Fig. 7, I. After an interval of $2 \mathrm{hr}$, competence rose slowly to a low level. 
In Fig. 7, III, the low oxygen tension had a stimulatory effect on glycolysis (Pasteur reaction) serving to increase the efficiency of an anaerobic supply of energy. In this case competence decreased to a low level and increased again after $5 \mathrm{hr} 30 \mathrm{~min}$. The peak of competence was lower than in the first case.

When shaking the bacteria was stopped during the development of competence the competence began to decrease at once.

When the bacterial cells were shaken after $5 \mathrm{hr}$ incubation, competence developed at once and its peak was the same as that found in the shaken culture.

Different quantities of spores (OD, 0.1 and 0.5 ) and $17 \mathrm{hr}$ cultures (OD 0.5 ) of Bacillus subtilis 168 try- were cultivated in MGY medium in the usual way. During growth samples were taken for the transformation (Fig. 8).

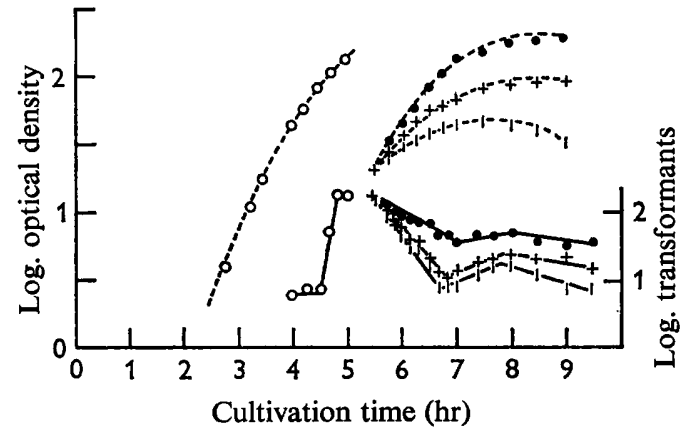

Fig. 9

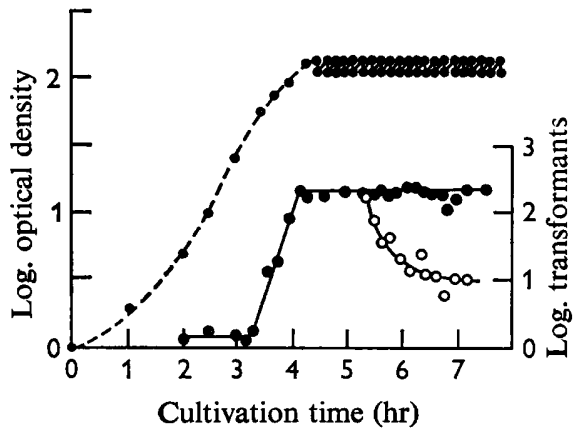

Fig. 10

Fig. 9. Changes of competence in media containing different compositions. - - -, Optical density; - , competence; 0 , values in medium $I ;+++$, values in medium 2 ; 1 | | |, values in medium 3; OO०, values in MGY liquid medium.

Fig. Io. Changes of competence in balanced growth cultures at $37^{\circ}$ and $0^{\circ}$. Optical density; $\longrightarrow$, the number of transformants at $37^{\circ} ; 0-0$, the number of transformants at $0^{\circ}$.

With an initial count of $2.46 \times 10^{7}$ spores $/ \mathrm{ml}$. competence developed after $3 \mathrm{hr}$ 30 min., quickly rose, and then decreased gradually (Fig. 8, I).

In Fig. 8, II. the initial spore count was $1 \cdot 23 \times 10^{8} / \mathrm{ml}$. Competence rose after $2 \mathrm{hr}$ 30 min. but the peak was lower than in Fig. 8, I.

The inoculum of bacterial cells $\left(2.95 \times 10^{8} / \mathrm{ml}\right.$.) was competent when they were taken from the agar slope, the peak of competence was high (Fig. 8. III).

The smaller the inoculum of spores, the later the time of the development of competence.

In the next experiment, bacteria were transferred from an overnight agar slope into MGY liquid medium to give an initial count of $10^{6} / \mathrm{ml}$. After $5 \mathrm{hr}$ incubation the cells became highly competent and were then sedimented at $1600 \mathrm{~g}$ for $5 \mathrm{~min}$. The packed organisms were resuspended in three media of the following compositions: (I) $\mathrm{M} / \mathrm{I} 5$ phosphate buffer ( $\mathrm{pH} 7$ ), $5 \mu \mathrm{g} / \mathrm{ml}$. L-tryptophan, $0.5 \%$ glucose, $0 . \mathrm{I} \%$ casein hydrolysate and $0.2 \%$ yeast extract: (2) the first without yeast extract; (3) the second with $0.02 \%$ casein hydrolysate.

The OD was adjusted to $0 \cdot 2$. The curves of competence determined by the usual procedure, using T-medium (Fig. 9). 
The decrease of competence was lower in minimal medium than in the complete one.

In the following experiment bacteria were inoculated into $10 \mathrm{ml}$. MGY medium at an initial count of $5 \times 10^{6} / \mathrm{ml}$. and incubated. When the bacteria showed maximal competence with a generation time of 55-60 min., balanced growth was initiated. A small portion of the organisms was taken after $5 \mathrm{hr} 20 \mathrm{~min}$. and put into an ice bath. The changes of competence were also followed in this bacterial suspension (Fig. 10).

When the organisms were kept at $0^{\circ}$ the competence decreased by I.I log. units after I hr.

\section{DISCUSSION}

Genetic transformation by free DNA is possible only when the bacterial cells become competent. But, despite many reports, this property of bacteria has not been well defined (Ravin, I956; Jensen \& Haas, I963; Spizizen, Reilly \& Evans, I966). The development of competence is influenced by both endogenous and exogenous factors which affect one another during growth.

One of the problems in the transformation procedure is that Bacillus subtilis strains which can be easily transformed contain organisms differing in competence so that the frequency of transformation is variable (Young \& Spizizen, 196I). In B. subtilis I 68 try , $^{-}$competence develops in late logarithmic growth when the bacteria multiply at a certain rate and it seems that this state may be associated with certain processes leading to sporulation (Young \& Spizizen, 196I; Spizizen, 1965; Young, 1967). Asporogenous mutants of $B$. subtilis which remained competent have been isolated (Schaeffer, 1964).

In 1963 a lytic factor was demonstrated in the wall in those strains of Bacillus subtilis which can be easily transformed (Young \& Spizizen, 1963; Young, Tipper \& Strominger, 1964). In B. subtilis strains (I68 try ${ }^{-}, \mathrm{I} 68 \mathrm{M}, \mathrm{SB}-25$, etc.) we have also found that the good transformable strains had a high autolytic effect, while others which could hardly be transformed showed a very low lytic effect. We could not find any definitive proof that this factor (extract of the bacteria, or competent bacterial culture filtrate) facilitated the transformation.

Charpak \& Dedonder (1965) demonstrated a substance in the supernatant of competent Bacillus subtilis 168 try- culture, and in the cell extract, which permitted transformation in a non-competent $B$. subtilis strain.

Exogenous factors, such as, the composition of the media, the temperature, and the inoculum size are also very important in the development of competence.

Many investigators use minimal media for transformation experiments (Anagnostopoulos \& Spizizen, 196I; Young \& Spizizen, 196I) but it was found here that if the bacteria are cultivated in MGY medium, the peak of competence is higher. There is no contradiction between these results. In a certain period of time competence is higher in a minimal medium and lower in a supplemented one; but the peak of competence is higher in the supplemented media when cultivation is continued. Competence also develops in MGY liquid media inoculated with spores of Bacillus subtilis I68 tryand in precultivated bacteria too. It also appears in bacteria cultivated on agar slope.

Other factors are also of importance. Aeration facilitates the development of competence, and when the supply of oxygen is decreased competence stops developing. In a previous paper (Horváth, 1967) we showed how the inoculum size influenced the 
development of competence. The smaller the bacterial inoculum, the shorter the time required for the rise phase of competence

The OD value of a bacterial suspension is a valuable guide to competence although its optimal value depends upon the inoculum size (Horváth, 1967), the medium, the strains used in the experiment.

One of the important factors is the generation time which is determined by a lot of factors. The optimal generation time for competence varies according to the strains and the cultural conditions. Its average value is $45-60 \mathrm{~min}$. which shows that most of the organisms are actively growing. In the pneumococcus transformation system, Tomasz (1965) also demonstrated that the competent cocci grew actively. Protein synthesis appears to be required for the maintenance of competence. Once organisms have an optimal level of competence, it is kept for some hours or decreases slowly. In this case the organisms might have a long generation time and it seems to be 'nongrowth' competent bacteria.

Singh \& Pitale (1967) could separate competent bacilli from actively dividing incompetent ones by zonal centrifugation of a culture of Bacillus subtilis in a sucrose gradient. Their results showed that competent bacilli were lighter than the incompetent.

In a closed culture competence appears when the growth medium becomes exhausted of some nutrients, and then increases very much faster than the growth rate of the bacteria. During cultivation, competence begins to decrease.

Competent bacteria are relatively resistant to penicillin, actinomycin D, and puromycin. They appear to be non-dividing organisms (Nester \& Stocker, 1963; Nester, 1964; Singh \& Pitale, 1967).

Hotchkiss (1954) obtained evidence in a pneumococcus transformation system that cell division played a role in the development of competence. With Bacillus subtilis no evidence was found that the division-synchrony of bacilli played such a role.

When the medium becomes exhausted the competence develops after the last cell division, and for that reason cell division plays a role in the development of competence. Because cell division is partly synchronous, waves of competence can be seen.

I should like to express my gratitude to Director Dr B. Györffy for his valuable instruction and to I. Kállay for her expert technical assistance.

\section{REFERENCES}

Abel, P. \& Trautner, T. A. (1964). Formation of an animal virus within a bacterium. $Z$. VererbLehre 95, 66.

Alexander, H. E. \& Redman, W. (1953). Transformation of type specificity of meningococci. Change in heritable type induced by type specific extracts containing deoxyribonucleic acid. $J$. exp. Med. 97, 797.

Anagnostopoulos, C. \& Spizizen, J. (196I). Requirements for transformation in Bacillus subtilis. J. Bact. 81, 74I.

Balassa, R. (1954). Transformations mechanismen der Rhizobien. Acta microbiol. Acad. Sci. hung. 2, 51 .

Bayreuther, K. E. \& Romig, W. R. (1964). Polyoma virus: production in Bacillus subtilis. Science, N.Y. 146, 778.

Bracco, R. M., Krauss, M. R., Roe, A. S. \& MacLeod, C. M. (I957). Transformation reactions between pneumococcus and three strains of streptococci. J. exp. Med. ro6, 247. 
Catuin, B. W. \& Cunningham, L.S. (1964). Genetic transformation of Neisseria catarrhalis by deoxyribonucleate preparations having different average base compositions. J. gen. Microbiol. 37, 34I.

Charpak, M. \& Dedonder, R. (1965). Production d'un 'facteur de compétence' soluble par Bacillus subtilis marburg ind ${ }^{-}$168. C. r. hebd. Séanc. Acad. Sci., Paris 5638.

COREY, R. R. \& STARR, M. P. (1957). Genetic transformation of Neisseria by culture slime containing deoxyribonucleate. Science, N.Y. r3I, 608.

GoOdGal, S. H. \& HeRriotT, R. M. (196I). Studies on transformation of Haemophilus influenzae. I. Competence. J. gen. Physiol. 44, I20I.

GREEN, D. M. (1964). Infectivity of DNA isolated from Bacillus subtilis bacteriophage, SP82. J. molec. Biol. ro, 438.

HoRvÁTH, S. (1967). Development of competence in cultures of Bacillus subtilis inoculated with different numbers of bacteria. J. gen. Microbiol. 48, 215.

Hoтchкiss, R. D. (1954). Cyclical behavior in pneumococcal growth and transformability occasioned by environmental changes. Proc. natn. Acad. Sci. U.S.A. 40, 49.

Hoтchкiss, R. D. (1957). Criteria for quantitative genetic transformation of bacteria. In The Chemical Basis of Heredity, p. 321. Baltimore: Johns Hopkins Press.

JeNSEN, R. A. \& HAAS, F. L. (I963). Elektrokinetics and cell physiology. II. Relationship of surface change to onset of bacterial competence for genetic transformation. J. Bact. 86, 79.

KLEIN, D. T. \& KLEIN, R. M. (I953). Transmittance of tumor-inducing ability to avirulent crown-gall and related bacteria. $J$. Bact. 66, 220.

NesTER, E. W. (1964). Penicillin resistance of competent cells in deoxyribonucleic acid transformation of Bacillus subtilis. J. Bact. 87, 867.

Nester, E. W. \& STOCKER, B. A. D. (1963). Biosynthetic latency in early stages of deoxyribonucleic acid transformation in Bacillus subtilis. J. Bact. 86, 785.

Okubo, S., Strauss, B. \& Stodolsky, M. (I964). The possible role of recombination in the infection of competent Bacillus subtilis by bacteriophage deoxyribonucleic acid. Virology 24, 552.

Ravin, A. W. (1956). The properties of bacterial transforming systems. Mutation. Brookhaven Symp. Biol. 8, 33.

ReILly, B. E. \& SPIZIZEN, J. (1965). Bacteriophage deoxyribonucleate infection of competent Bacillus subtilis. J. Bact. 89, 782.

Romig, W. R. (1962). Infection of Bacillus subtilis with phenol extracted bacteriophages. Virology 16, 452.

SaIto, H. \& MiURA, K. I. (I963). Preparation of transforming deoxyribonucleic acid by phenol treatment. Biochim. biophys. Acta 72, 619.

SChaEfFer, P. (1964). Transformation. In The Bacteria. Ed. by I. C. Gunsalus and R. Y. Stanier, vol. 5, p. 87. New York: Academic Press.

Singh, R. N. \& Pitale, M. P. (1967). Enrichment of Bacillus subtilis transformants by zonal centrifugation. Nature, Lond. $213,1262$.

SpIzIzEN, J. (1958). Transformation of a biochemically deficient strain of Bacillus subtilis by deoxyribonucleate. Proc. natn. Acad. Sci. U.S.A. 44, 1072.

SpIzIZEN, J. (1965). Analysis of asporogenic mutants in Bacillus subtilis by genetic transformation. In Spores III. Ed. by L. L. Campbell and H. O. Halvorson, p. I25. Ann Arbor: Am. Soc. Microbiol.

Spizizen, J., Reilly, B. E. \& Evans, A. H. (1966). Microbial transformation and transfection. A. Rev. Microbiol. 20, 37I.

Tomasz, A. (1965). Control of the competent state in Pneumococcus by a hormone-like cell product: An example for a new type of regulatory mechanism in bacteria. Nature, Lond. 208, 155.

Young, F. E. (1967). Competence in Bacillus subtilis transformation system. Nature, Lond. 213, 773.

Young, F. E. \& SpIZizen, J. (196I). Physiological and genetic factors affecting transformation of Bacillus subtilis. J. Bact. 81, 823.

Young, F. E. \& SpIzIZEN, J. (1963). Biochemical aspect of competence in the Bacillus subtilis transformation system. J. biol. Chem. 238, 3126.

Young, F. E., TipPer, J. \& Strominger, J. L. (1964). Autolysis of cell walls of Bacillus subtilis. Mechanism and possible relationship to competence. J. biol. Chem. 239, PC 3600. 